\title{
Examination of the content of heavy metals using hair samples in dogs of urban areas of Macedonia
}

\author{
Elena Atanaskova ${ }^{1}$, Goran Nikolovski ${ }^{1}$, I gor Ulčar ${ }^{2}$ and Vangelica Enimiteva ${ }^{3}$ \\ Faculty of Veterinary Medicine, Skopje, Macedonia \\ 1. Department of internal medicine of companion animals and horses, \\ 2. Department of pathophysiology 3. Laboratory for residues and contaminants \\ * Corresponding author email: eatanaskova@fvm.ukim.edu.mk \\ phone number +3892 3240778; fax +38923240700 \\ Received : 09-03-2011 Accepted : 13-04-2011, Published Online: 04-06-2011
}

\begin{abstract}
Dogs can be very good indicators for the environmental pollution. They share the same environment as humans and are exposed to action of the same pollutants. Contamination of the environment with heavy metals is performed by emissions of different origin, especially present in the urban areas. That is why it was great advantage to analyze the heavy metal levels in dogs from several urban areas in Macedonia. The objectives of this study were examination and analyzing the content of two heavy metals: cadmium and lead in dogs. For these purposes dog's hair samples were used. Samples were collected from $35 \mathrm{dogs}$ from different localities. They were analyzed using the method of atomic absorption spectrometry. Statistical data processing was performed. Mean lead level in the hair samples from Veles, Bitola and Prilep were: 930.15, 715.66 and $525.63 \mu \mathrm{g} / \mathrm{kg}$; while for cadmium were: $54.28,42.65$ and $27.82 \mu \mathrm{g} / \mathrm{kg}$ respectively. According to reference intervals for hair elements all the values are in normal ranges (for $\mathrm{Cd}<100 \mu \mathrm{g} / \mathrm{kg}$, and for $\mathrm{Pb}<2000 \mu \mathrm{g} / \mathrm{kg}$ ). Comparison of the results between these areas showed significance in arithmetic means $(<0.05)$ between Veles and Prilep for $\mathrm{Pb}$ and absolute significance $(<0.001)$ in arithmetic means for $\mathrm{Cd}$ between Veles and Prilep. The study presents the need for further research in this area, using dogs as bioindicators.
\end{abstract}

Key words: atomic absorption spectrometry, heavy metals, dog's hair.

\section{I ntroduction}

Our environment is affected by a great variety of pollutants. Most often present are lead and cadmium. They have no physiological function in the organism. According to some authors ( 2 and 9) the main sources of lead contamination are smelting works, application of wastewater treatment sludge to soil, transportation, rain, snow and others. About $98 \%$ of lead in the atmosphere originates from human activities. Lead enters the organisms with food and air. Cadmium presence is the organism is also unwanted and harmful. It occurs naturally in high abundance in zinc and lead ores and phosphate fertilizers. (12)

Lead toxic effects are various in human from central nervous system in children, shortening the gravity, decrease in birth weight, retardation of mental development. In animals, lead causes softening of the bones and decreased productivity. Prolonged increased uptake of cadmium interferes with the function of the kidneys; disturbs metabolism of calcium which affects bone tissue. $(13,4)$
Dogs share the same environment as humans, develop many of the same diseases and therefore are considered to be the possible official sentinels for environmental metal pollution. Dogs living in mining, smelting industrial and urban environment have been reported to have higher blood lead level than those in rural environment. (1)

Different biological materials from dogs have been used. Often, as biological material for determination of heavy metal exposure animal's hair have been recommended. $(1,7)$ The hair has constant rite of growing and can be used for determination of metals in different periods in the past. Also, obtaining hair samples is relatively easy.

\section{Materials and methods}

Dog hair samples were collected in the period of March to September 2010 from three urban areas of Macedonia. About $2 \mathrm{~g}$ of hair was taken from the lower neck area, cut near to the skin with scissors. The hair samples were packed in little plastic bags and stored in refrigerator till the analyses. 
Examination of the content of heavy metals using hair samples in dogs of urban areas of Macedonia

Table-1. The content of heavy metals in dogs with descriptive statics

\begin{tabular}{|c|c|c|c|c|c|}
\hline Heavy metal, town & Number & Mean $\mu \mathrm{g} / \mathbf{k g}$ & Minimum $\mu \mathrm{g} / \mathbf{k g}$ & Maximum $\mu \mathrm{g} / \mathrm{kg}$ & STDEV \\
\hline$\overline{\mathrm{Pb} \text {, Veles }}$ & 11 & 930,15 & 220,26 & 1878,75 & 516,03 \\
\hline Cd, Veles & 11 & 54,28 & 32,14 & 69,00 & 12,77 \\
\hline Cd, Bitola & 13 & 42,65 & 14,46 & 99,71 & 25,41 \\
\hline $\mathrm{Pb}$, Prilep & 11 & 525,63 & 156,43 & 987,54 & 253,91 \\
\hline Cd, Prilep & 11 & 27,82 & 16,90 & 46,25 & 8,31 \\
\hline
\end{tabular}

Table-2. T-test for Independent Samples (Variables were treated as independent samples)

\begin{tabular}{|c|c|c|c|c|c|}
\hline & Mean & Mean & t-value & df & $\mathbf{p}$ \\
\hline $\mathrm{Pb}$ Ve vs. $\mathrm{Pb} \mathrm{Bt}$ & 930,15 & 715,66 & 1,28 & 22 & 0,21 \\
\hline $\mathrm{Pb}$ Ve vs. $\mathrm{Pb} \mathrm{Pp}$ & 930,15 & 525,63 & 2,33 & 20 & $<0,05$ \\
\hline $\mathrm{Pb}$ Bt vs. Pb Pp & 715,66 & 525,63 & 1,68 & 22 & 0,11 \\
\hline Cd Ve vs. Cd Pp & 54,28 & 27,82 & 5,76 & 20 & $<0,001$ \\
\hline Cd Bt vs. Cd Pp & 42,65 & 27,82 & 1,85 & 22 & 0,08 \\
\hline Pb Sum vs. Pb Ve & 723,35 & 930,15 & $-1,41$ & 44 & 0,16 \\
\hline Pb Sum vs. Pb Pp & 723,35 & 525,63 & 1,56 & 44 & 0,12 \\
\hline Cd Sum vs. Cd Ve & 41,64 & 54,28 & $-1,94$ & 44 & 0,06 \\
\hline Cd Sum vs. Cd Bt & 41,64 & 42,65 & $-0,14$ & 46 & 0,89 \\
\hline Cd Sum vs. Cd Pp & 41,64 & 27,82 & 2,19 & 44 & $<0,05$ \\
\hline
\end{tabular}

Veles- Ve; Bitola- Bt; Prilep- Pp; Sum- Summary

The total number of samples was 35: 11 hair samples taken from Veles, 13 from Bitola and 11 from Prilep. All the dogs were kept consistently as companion animals.

Hair samples were washed with distilled water and then every hair sample was placed in Kjeldahl flasks and immersed with acetone. After this the samples were leached trough filter paper, sunken in un-ionizing detergent TRITON X-100 (polyethylene glycol p-(1,1,3,3 tetramethylbutyl) phenyl, Merck, Germany); then washed at least 3 times with redistilled water; the hair was dried in drier on $105^{\circ} \mathrm{C}$ till the chemicals evaporate and then were measured on analytic scale. (6). Prepared this way the samples were ready for wet mineralization with $69 \%$ nitrogen acid (Nitric Acid 69\% Tracepur 69\%, Merck, Germany) $0,25 \mathrm{ml}$ for every hair sample and $30 \%$ hydrogen peroxide (Merck, Germany) 0,1ml. After these the samples were placed in digester on sand bath Combiplac Selecta $P$ which has thermoregulation. Every sample was moderately warmed and evaporated, till small clean extract was gained. This liquid extract was transferred to $25 \mathrm{ml}$ colba and supplemented with redistilled water. This solution was ready for the measurement. Lead and Cadmium levels in the hair samples were identified by atomic absorption spectrometer type Perkin Elmer AAnalyst 600. The atomization took place in a graphite cell, type HGA 700, in an argon atmosphere using wavelengths $283,3 \mathrm{~nm}$ for $\mathrm{Pb}$ and $228,8 \mathrm{~nm}$ for $\mathrm{Cd}$. Before every measurement of the samples, standards were measured first: Lead standard solution $\gamma \mathrm{Pb}=1000+/-2 \mathrm{mg} / \mathrm{L}$ (Merck, Germany); Cadmium standard solution $\gamma \mathrm{Cd}=1000$ +/-2mg/L (Merck, Germany).

After measuring the standards, blind samples were measured. With entering the weight/volume of the hair sample and volume of the solution before the measurement, the instrument's program automatically performs each calculation separately. After the calibration, measuring of the samples was performed. The technique of ETAAS was used; due to the low concentrations of heavy metals in the samples. Statistical data processing was performed with the program Statistica 6.0 Statsoft.

\section{Results}

The mean value of lead and cadmium in the hair samples from all urban areas were $723.35 \mu \mathrm{g} / \mathrm{kg}$ and $41.64 \mu \mathrm{g} / \mathrm{kg}$, which are in permitted concentration. (3) Mean levels of $\mathrm{Pb}$ and $\mathrm{Cd}$ by cities together with the ranges and STDEV, are given in Table-1. The mean levels of $\mathrm{Pb}$ and $\mathrm{Cd}$ are: Veles 930.15 and 54.28; Bitola 715.66 and 42.65; Prilep 525.63 and 27.82. The comparison of the results between the different areas showed a complete significance in arithmetic means between Veles and Prilep $(\mathrm{p}<0.001)$ for $\mathrm{Cd}$ and significant $(<0.05)$ for $\mathrm{Pb}$ (table 2$)$.

The wide range of the heavy metals levels in the 
samples presented by cities (table1) is directly related to the different ages of the examined dogs. The ranges of the total mean values are wide due to the different pollution of the explored locations. After all, mean values showed the difference of the heavy metal pollution in the different environments.

\section{Discussion}

Generally main sources of accumulation of heavy metals in the environment are local point sources which emit heavy metals in their immediate environment. (10)

Many authors had paid attention to dogs as bioindicators of pollution $(1,5,7)$. The method that was used in this study is very similar to the one used in the study of Kozak M., et al (5) with Perkin-Elmer spectrometer, model 5000. Masatoshi Hayashi et al, (8) used the same atomic absorption spectrometry with Perkin-Elmer spectrometer, model 2100.

According to the referent intervals given for lead $(<2000 \mu \mathrm{g} / \mathrm{kg})$ and cadmium $(<100 \mu \mathrm{g} / \mathrm{kg})$ in human hair by Erten $\mathrm{J}$ et al (3), all of the examined dogs were in normal ranges. Some of them were closer to the upper limit, due to the contamination of the area. However we can say that the urban areas of Republic of Macedonia are relatively unpolluted.

The level of lead and cadmium in the urban areas of Macedonia $(723.35 \mu \mathrm{g} / \mathrm{kg}$ and $41.64 \mu \mathrm{g} / \mathrm{kg})$ is lower than the results gained by Masatoshi Hayashi et al, (8) $(1890 \mu \mathrm{g} / \mathrm{kg} ; 390 \mu \mathrm{g} / \mathrm{kg})$ in Tokyo and by Park S.H et al (11) $(820 \mu \mathrm{g} / \mathrm{kg} ; 90 \mu \mathrm{g} / \mathrm{kg})$ from urban Korea. Our results were higher than those gained by Kozak M et al (6) $(601.90 \mu \mathrm{g} / \mathrm{kg} ; 27.40 \mu \mathrm{g} / \mathrm{kg})$ in urban areas of Slovakia.

The hair samples from the region where the lead has been depositing in the environment had higher mean level, like in Veles. At about $5 \mathrm{~km}$ from Veles exists the Lead-Zinc smelter which had worked over 20 years till the 2004 . The mean cadmium and lead level was lowest in the hair samples from Prilep $(27.82 \mu \mathrm{g} / \mathrm{kg} ; 525.63 \mu \mathrm{g} / \mathrm{kg})$. One half of the hair samples from Bitola were from areas near to the Mining Power Complex (TPP Bitola) that may have a role in pollution of the environment. This may be the reason why Bitola has higher lead and cadmium levels from Priler besides the closeness to these two towns $(45 \mathrm{~km})$.

This study aims to encourage further similar researches of the environmental pollution in Macedonia and beyond. Evaluation of heavy metals in hair samples is only a part of the parameters that can be examined for illustration of the environmental pollution. Water and soil examinations together with proving the presence of heavy metals in animals can give a full picture of the environmental pollution.

In this modern world, the environmental pollution is a serious problem that we have to deal with. The health problems arising from the pollution with heavy metals can be removed by progressive improvement of our environment. From this study we can realize that man with various activities contributes to the pollution, because the results showed great correlation between human activities and environmental pollution.

\section{Acknowledgement}

We would like to thank the Dean of the Faculty of Veterinary Medicine, Skopje, Professor Dine Mitrov for providing the necessary finance support for this study.

\section{References}

1. Balagangatharathilagar, M.; Swarup, D.; Patra, R.C.; Dwivedi, S.K. (2006): Blood lead level in dogs from urban and rural areas of India and its relation to animal and environmental variables. Sci. Total. Environ., 359: 130-134.

2. Cibulka, J. (1991): Transfer of Lead, Cadmium and Mercury in the Biosphere. Academia Praha, 426-427.

3. Erten, J.; Arcasoy, A.; Cavdar, A.O.; Cin, S. (1978): Hair zinc levels in healthy and malnourished children. Am. J. Clin. Nutr., 31: 1172-1174.

4. Ginter, E. (1993): Cadmium as a toxic environmental contaminant. Proc. Ecology and Life II, 3: 14-15.

5. Krejpdo, Z.; Olejnik, D.; Wojciak, R.W.; Gawecki, J. (1999): Comparison of trace element in the hair of children inhabiting areas of different environmental pollution types. Pol. J. Environ. Stud., 8: 227-229.

6. Kozak, M.; Kralova, E.; Sviatko, P.; Bilek, J.; Bugarsky, A. (2002): Study of the content of heavy metals related to environmental load in urban areas in Slovakia. Bratisl. Lek. Listry., 103 (7-8): 231-237.

7. López-Alonso, M.; Miranda, M.; Garcia-Partida, P.; Cantero, F.; Hernandez, J.; Benedito, J. L. (2002): Use of dogs as indicators of metal exposure in rural and urban habitans in NW Spain. Sci. Total. Environ., 372: 668-675.

8. Masatoshi, H.; Isami, O.; Hirishi, T.; Yoshikazu, M.; Shuji, O.; Yoichi, Y. (1981): Distribution of Environmental Pollutants in Pet Animals. VI. Heavy Metals in Hair of House-dogs. Bull. Environm. Contam. Toxicol., 26: 60-64.

9. Neumann, J.; Lopuchovský, J.; Zapletal, O. (1990): Chemisation, Agricultuture, Pharmacology and Toxicology, $1^{\text {st }}$ edition, pp.340, SZN Praha.

10. Ondrašovič, M.; Ondrašovičová, O.; Para L' Kočišová, A. (1993): Veterinary Care about the Environment - Practical Lessons. pp.153, UVM Košice.

11. Park, S.H.; Lee, M.H.; Kim, S.K. (2005): Studies on Cd, Pb, $\mathrm{Hg}$ and $\mathrm{Cr}$ values in dog hairs from urban Korea. Asian. Austral. J. Anim., 18: 1135-1140.

12. Satarug, S.; Baker, J. R.; Urbenjapol, S.; Haswell-Elkins, M.; Reilly, P.E.B.; Williams, D.J.; Moore, M. R. (2003): A global perspective on cadmium pollution end toxicity in nonoccupationally exposed population. Toxicol. Lett., 137: 65-83.

13. Šmirjákova, S.; Ondrašovičová, O.; Kašková, A.; Laktičová, K. (2005): The effect of cadmium and lead pollution on human and animal health. Folia Vet., 49(3): 31-32. 